\title{
II. On arctic interglacial periods
}

\author{
James Croll LL.D. F.R.S.
}

To cite this article: James Croll LL.D. F.R.S. (1885) II. On arctic interglacial periods, Philosophical Magazine Series 5, 19:116, 30-42, DOI: 10.1080/14786448508627636

To link to this article: http://dx.doi.org/10.1080/14786448508627636

册Published online: 29 Apr 2009.

Submit your article to this journal 준

Џll Article views: 2

Q View related articles $₫$ 
II. On Arctic Interglacial Periods. By J AMes CROLL, LL.D., F.R.S.*

D OLAR Interglacial Periods more marked than the Glacial. -In a former paper $\dagger$, and also in 'Climate and Time' (chap. xvi.), it was pointed out that in temperate regions the cold periods of the glacial epoch would be far more marked than the warm interglacial periods. In temperate regions the condition of things which prevailed during the cold periods would differ far more widely from that which now prevails than would the condition of things during the warm periods. But as regards the polar regions the reverse would be the case; there the warm interglacial periods would be more marked than the cold periods. The condition of things prevailing in these regions during the warm periods would be in strongest contrast to what now obtains; but this would not hold true in reference to the cold periods, during which matters would be pretty much the same as at present, only somewhat more severe. In short, the glacial state is the normal condition of the polar regions, the interglacial the abnormal. At present Greenland and other parts of the Arctic regions are almost wholly covered with snow and ice, and, consequently, nearly destitute of vegetable life. In fact, as regards organic life in those regions, matters during the glacial epoch would not probably be much worse than they are at the present day. Greenland and the Antaretic continent are to-day almost as destitute of plant-life as they could possibly be. Although, in opposition to what is found to be true in reference to the temperate regions, the polar interglacial periods were more marked than the glacial, it does not follow that on this account the relics of the interglacial periods which remain ought to be more abundant in polar than in temperate regions. On the contrary, the reverse ought to be the case. In the polar regions, undoubtedly, there is least likelihood of finding traces of interglacial periods ; for there, of all other places, the destruction of such traces would be most complete. The more severe the glaciation following a warm period, the more complete would be the removal of the remains belonging to the period. If in such places as Scotland and Scandinavia so little is left of the wreck of interglacial periods, it need be a matter of no surprise that in Arctic regions scarcely a relic of those periods remains. The comparative absence in polar regions of

* Communicated by the Author.

+ Phil. Mag. May 1884, p. 375; American Journal of Science, Jure1884. 
organic remains belonging to a mild interglacial period cannot therefore be adduced as evidence against the probable existence of such a period. Who would expect to find such remains in ice-covered regions like Greenland and Spitzbergen? Although not a trace is now to be found, it is nevertheless quite possible that during interglacial periods those regions may have enjoyed a comparatively mild and equable climate.

Evidence from the Mammoth in Siberia.-This comparative absence of the remains of a warmer condition of climate in Arctic regions during Pleistocene times holds true, however, only in regard to those parts, like Greenland, which have undergone severe glaciation. When we examine Siberia and other places which appear to have escaped the destructive power of the ice, we find, from a class of facts the physical importance of which appears to have been greatly overlooked, abundant proofs of a mild and equable condition of climate. I refer to facts connected with the climatic condition under which the Siberian Mammoth and his congeners lived. The simple fact that the Mammoth lived in Northern Siberia proves that at the time the climate of that region must have been far different from what it is at the present day.

The opinion was long held, and is still held by some, that the Mammoth did not live in Northern Siberia, where his remains are found, but in more southern latitudes, and that these remains were carried down by rivers. It was considered incredible that an animal allied to the Elephant, which now lives only in tropical regions, should have existed under a climate so rigorous as that of Siberia. The opinion that the remains were floated down the Siberian rivers is now, however, abandoned by Russian naturalists and other observers who have carefully examined the country.

I shall here give a brief statement of the facts and arguments which have been adduced in support of the theory that the Mammoth lived and died where its remains were found. For these facts I am mainly indebted to the admirable papers by Mr. Howorth on the "Mammoth in Siberia," which appeared in the 'Geological Magazine' for 1880.

Had the remains of the Mammoth been carried down from the far south by the Siberian rivers, they would have been found mainly, if not exclusively, on the banks of the long rivers, such as the Obi, Yenissei, and the Lema, and in the deltas formed at their mouths. But such is not the case. "Ihese are," says Mr. Howorth, "found even more abundantly on the banks of the very short rivers east of the Lena. They are found not only on the deltas of these rivers, but far 
away to the north, in the islands of New Siberia, beyond the reach of the currents of the small rivers, whose mouths are opposite those islands." But a more convincing proof is that "they are found not only in North Central Siberia, where the main arteries of the country flow, but in great numbers east of the river Lena, in the vast peninsula of the Chukchi, in the country of the Yukagirs, and in Kamtskatka, where there are no rivers down which they could have floated from more temperate regions." Besides, it is not merely in the deltas and banks of rivers that the remains are found, but in nearly all parts of the open tundra; and Wrangell says* that the best as well as the greatest number of remains are found at a certain depth below the surface in clay-hills, and more in those of some elevation than along the low coast or in the flat tundra.

Had the Mammoth lived in the south we should, as Mr. Howorth further remarks, have found its remains most abundant in the south, whereas the further north we go the remains become more abundant, and in the islands of the Liachof archipelago, in about latitude $74^{\circ}$, the greatest quantities have been discovered. Again, according to Hedenstrom, the bones and tusks found in the north are not so large and heavy as those in the south; a fact which still further confirms the opinion that the Mammoth lived where his remains are found, inasmuch as the greater severity of the climate in northern parts would certainly hinder the growth and full development of the animal.

Northern Siberia much Warmer during the Mammoth Epoch than now.-It is true that the Mammoth and the Rhinoceros tichorhinus were furnished with a woolly covering which would protect them from cold; but it is nevertheless highly improbable that they could have endured a climate so severe as that of Northern Siberia at the present day, where the ground is covered with snow for nine months in the year and the temperature is seldom much above zero Fahr. And even if they could have endured the cold, they would have starved for want of food. Some parts of Siberia are no doubt fertile, as, for example, the valley of the Yenisei, described by Nordenskjöld $\dagger$; but there is little doubt, as $\mathrm{Mr}$. Howorth remarks, that the larger portion of Northern Siberia, where the Mammoth and the Rhinoceros lived, is now a naked tundra covered with moss, on which no tree will grow. On such ground it is physically impossible that the Mammoth and Rhinoceros could exist, for they cannot graze close to

* 'Polar Sea Expedition,' English translation, p. 275.

$\dagger$ 'Nature,' Dec. 2, 1875 . 
the ground like oxen. They live on long grass and on the foliage and small branches of trees.

Evidence from Wood.-The fact that the Mammoth was most abundant beyond the present northern limit of wood is pretty good evidence that the climatic condition of Northern Siberia must have been milder than now. Wood must have extended, in the days of the Mammoth, far beyond its present, limit, probably as far north as New Siberia : facts of observation support this conclusion.

The wood found in Northern Siberia consists of two classes-the one is the result of drift, the other grew on the spot. The natives call the former "Noashina," and the latter "Adamshina;" and the division is supported by Göppert, "who separates the trunks of timber found in Northern Siberia into a northern series, with narrow rings of annual growth, and a southern, with wider ones. The latter doubtless floated down the rivers, as great quantities do still; while the former probably grew here with the Mammoth."

In the middle of October 1810 Hedenstrom went across the tundra direct to Ustiansk. "On this occasion," he says, "I observed a remarkable natural phenomenon on the Chastach Lake. This lake is 14 versts long and 6 broad, and every autumn throws up a quantity of bituminous fragments of wood, with which its shores in many places are covered to the depth of more than 2 feet. Among these are pieces of a hard transparent resinous substance, burning like amber, though without its agreeable perfume. It is probably the hardened resin of the larch tree. The Chastach Lake is situated 115 versts from the sea and 80 versts from the nearest forest." *

On the same journey Hedenstrom noticed " on the tundra, equally remote from the present line of forest, among the steep sandy banks of the lakes and rivers, large birch trees, complete, with bark, branches, and root. At the first glance they appeared to have been well preserved by the earth; but, on digging them up, they are found to be in a thorough state of decay. On being lighted they glow, but never emit a flame: nevertheless the inhabitants of the neighbourhood use them as fuel, and designate these subterranean trees as Adamoushtshina, or of Adam's time. The first living birch tree is not found nearer than three degrees to the south, and then only in the form of a shrub." $\dagger$

On the hills in the interior of the island of Koteloni "Sannikow found the skulls and bones of horses, buffaloes,

* Wrangell, p. 491. $\dagger$ Ibid. p. 492.

Plit. Mag. S. 5. Vol. 19. No. 116. J $(n n .1885$. 
oxen, and sheep in such abundance that these animals must formerly have lived there in large herds. At present, however, the icy wilderness produces nothing that could afford them nourishment, nor would they be able to endure the climate. Sannikow concludes that a milder climate must formerly have prevailed here, and that these animals may therefore have been contemporary with the Mammoth, whose remains are found in every part of the island." *

"Herr von Ruprecht reported to Brandt that, at the mouth of the Indiga, in $67^{\circ} 39^{\prime} \mathrm{N}$. lat., on a small peninsula called Chernoi Noss, where at present only very small birch bushes grow, he found rotten birch trunks still standing upright, of the thickness of a man's leg and the height of a man. In going up the river be met with no traces of wood until he reached the port of Indiga. Here he noticed the first lightfir woods growing among still standing but dead trunks. And higher up the river still, the living woods fairly began." $\dagger$

Schmidt says that, "where the lakes on the tundra have grown small and shallow, we find on and near their banks a layer of turf, under which, in many places, are remains of trees in good condition, which support the other proofs that the northern limit of trees has retrogressed, and that the climate here has grown colder. I found, on the way from Dudino to the Ural Mountains, in a place where larches now only grow in sheltered rivervalleys, in turf on the top of the tundra, prostrate larch trees still bearing cones." $¥$

Schmidt also states that he was informed that at Dudino, just at the limit of the woods, there had been found in a miserable larch wood the lower part of a stem sticking in the ground, apparently rooted, which was three feet in diameter. $\mathrm{He}$ also states that, "eleven versts above Krestowkoje, in lat. $72^{\circ}$, he found, in a layer of soil covered with clay on the upper edge of the banks of the Yenissei, well-preserved stems like those of the birch, with their bark intact, and sometimes with their roots attached, and three to four inches in diameter. Professor Merklin recognizes them as those of the Alnaster fruticosus, which still grows as a bush on the islands of the Yenissei, in lat. $701^{\circ} \mathrm{N} . "$

Evidence from Shells.-In the freshwater deposits in which the bones of the Mammoth are found, there are freshwaterand land-shells, which indicate a warmer condition of climate. I quote the following from Mr. Howorth's memoir :-

"Schmidt found Helix schrencki in freshwater deposits on

* Wrangell, p. 496.

$\uparrow$ Bull. of Soc. of Nat. of Moscow ; quoted by Howorth.

$\ddagger$ Schmidt, as quoted by Howortb. 
the tundra below Dudino and beyond the present range of trees. Lopatim found recent shells of it, with well-preserved colours, $9^{\circ}$ further south, in lat. $68^{\circ}$ and $69^{\circ}$, within the present range of trees, at the mouth of the Awamka. The most northern limit hitherto known for this shell was in lat. $60^{\circ} \mathrm{N}$., where they were found by Maak in gold-washings on the Pit."

"In the freshwater clay of the tundra by Tolstoi Noss, Schmidt found Planovlis albus, Valvata eristata, and Limncea auricularia in a subfossil state; Cyclas calyculata and Valvata piscinalis he found thrown up on the banks of the Yenissei, and on a rotten drifted trunk, Limax agrestis; Anodonta anatina he also found on the banks of the Yenissei as far as Tolstoi Noss, but no further. Pisidium fontinale still lives in the pools on the tundra; as does Succinea putris on the branches of the Alnaster on the Brijochof Islands."

Mr. Belt mentions* that the Cyrena fluminalis is found in Siberia in the same deposits which contain the remains of the Mammoth and the Rhinoceros tichorlinus.

"The evidence, then," says Mr. Howorth, "of the débris of vegetation, and of the freshwater- and land-shells found with the Mammoth-remains, amply confirms the $\dot{a}$ priori conclusion that the climate of Northern Siberia was at the epoch of the Mammoth much more temperate than now. It seems that the botanical facies of the district was not unlike that of Southern Siberia, that the larch, the willow, and the Alnaster were probably the prevailing trees, that the limit of woods extended far to the north of its present range and doubtless as far as the Arctic Sea; that not only the mecn temperature was much higher, but it is probable that the winters were of a temperate and not of an Arctic type." (Geol. Mag. Dec. 1880.)

The Manmoth In erglacial.-it need be a matter of no surprise that the climate of Northern Siberia during the time of the Mammoth was more mild and equable than now, if we only admit that the Mammoth was interglacial. That it was of interglacial age is a conclusion which, I think, has been well established by Prof. J. Geikie and others. Into the facts and arguments which have been advanced in support of this conclusion I need not here enter. The subject will, however, be found discussed at great length in Prof. Geikie's 'Prehistoric Europe' and in 'The Great Ice-Age' (second edition). Mr. R. A. Wallace considers that one of the last intercalated mild periods of the glacial epoch seems to offer all the necessary conditions for the existence of the Mammoth in Siberia. That the Mammoth was interglacial will be further evident when we consider the climatic conditions of Europe at the * Quart. Journ. Geol. Soc. vol. xxx. p 464. 
time that it lived there. Before doing so, it may be as well to glance at what evidently were the main characteristics of the interglacial periods.

Main Characteristics of Interglacial Climate.-They are as follows :-

1. Interglacial conditions neither did nor could exist simultaneously on both hemispheres. They existed only on one hemisphere at a time, viz. on the hemisphere which had its winter solstice in perihelion.

2. During interglacial periods the climate was more equalle than it is at present; that is to say, the difference between the summer and winter temperatures was much less than it is now. The summers may not have been warmer or even so warm as they are at present, but the temperature of the winters was much above what it is at the present day.

3. During interglacial periods the quantity of equatorial heat conveyed by ocean-currents into temperate and polar regions was far in excess of what it is at present. On this account a greater uniformity of climate then prevailed: that is to say, the difference of climatic conditions between the subtropical and the temperate and polar regions was less marked than at present-the temperature not differing so much with latitude as it now does.

4. Mildness, or a comparative absence of high winds, characterized interglacial climate. This partial exemption from high winds resulted from the fact that the difference of temperature between the equator and the poles, the primary cause of the winds, was much less than at the present day.

5. Another character of interglacial climate was a higher mean temperature than now prevails. This, amongst other causes, resulted from the great amount of heat then transferred by ocean-currents from the glacial to the interglacial hemisphere.

6. During interglacial periods the climate was not only more equable, mild, and uniform than now, but it was also more moist. This was doubtless owing mainly to the fact of the presence then in temperate and polar regions of so large an amount of warm intertropical water. In short, it was the presence of so much warm water from intertropical regions which mainly gave to the climate of the interglacial periods its peculiar character.

All these characteristics of interglacial climate have been fully established by the facts of geology, but they are also, as we have seen, deducible à priori from physical principles. They follow as necessary consequences from those plysical agencies which brought about the glacial epoch. 
Evidence from the Mammoth in Europe.-Skeletons and detached remains of the Mammoth have been found in nearly every country in Europe. Mr. Howorth, in his memoir*, gives the details of the finding of these in various parts of Russia, Germany, Denmark, Sweden, Belgium, France, England, and other countries. It is shown that the conditions under which the Mammoth-remains have been found in Europe are almost identically the same as those under which they are found in Siberia, with the exception, of course, that in Europe no carcases with their flesh intact have been met with.

Again, the deposit in which the Mammoth-remains are found in Europe is the same as that in which they occur in Siberia. The deposit is a freshwater one, consisting of marly clay and gravel, and containing plant-remains and land- and freshwater-shells. When these plants and shells are examined, they are found to indicate the same interglacial condition of climate as that which prevailed in Siberia during the time the Mammoth lived in that region.

In the case of land-plants it is, of course, only under exceptional circumstances, as Prof. J. Geikie remarks, that they can be found in a condition suitable for the botanist. Now and again, however, beds with well-preserved plants are met with, buried under lacustrine deposits. In a still better state of preservation are the plant-remains and shells which have been discovered in the masses of calcareous tufa which have been formed upon the borders of incrustating springs. An examination of the plant-remains found under those conditions shows that during Pleistocene times, when the deposits in which the Mammoth bones are found were being formed, the climate was more equable and uniform than it is at the present day.

The fossiliferous remains yielded by the tufas have led to most important results as to the climatic condition of the Pleistocene period, into the details of which I need not here enter. These will be found at full length in Prof. J. Geikie's 'Prehistoric Europe,' chap. iv. $\dagger$ It will suffice at present simply to refer to the general conclusions to which these researches have led, in so far as they bear on the climatic conditions prevailing at the time the Mammoth lived so abundantly in Europe.

In the tufa deposits of Tuscany have been found numbers of plant-remains of indigenous species, commingled with others which now no longer grow in Tuscany. Amongst the latter is the Canary laurel, which now flourishes so luxuriantly in the Canary Islands, on the northern slopes of the mountains,

* Geol. Mag. May 1881.

$\dagger$ See also Mr. Howorth's memoir, Geol. Mag. June 1881. 
at an elevation of from 2000 to 5000 feet above the sea-levela region, remarks Prof. J. Geikie, nearly always enveloped in steaming vapours, and exposed to heavy rains in winter. In that deposit is also found the common laurel, associated with the beech. This is not now the case, as the laurel requires more shade than it can find there at present, while the beech has retreated to the northern flanks of the Apennines to obtain a cooler climate.

In the tufas of Provence are found groups the same as those which flourish there at present, but commingled with them are also the Canary laurel and other plants which are no longer natives of Provence. Saporta directs attention to the fuct that species such as the Aleppo pine and the olive, demanding considerable summer-heat rather than a moist climate, are entirely wanting in the tufas.

Similar to those of Provence are the tufas of Montpellier. Saporta concludes that when all those species lived together the climate must necessarily have been more equable and humid than at present. In other words, the summers were not so dry and the winters were milder than they are now.

The deposit near Moret, in the valley of the Seine, is still more remarkable in showing the equable condition of climate which then prevailed. The assemblage of plants found there tells a tale, says Prof. J. Geikie, which there is no possibility of misreading. "Here," he says, "we have the clearest evidence of a genial, humid, and equable climate having formerly characterized Northern France. The presence of the laurel, and that variety of it which is most susceptible to cold, shows us that the winters must have been mild, for this plant flowers during that season, and repeated frosts, says Saporta, would prevent it reproducing its kind. It is a mild winter rather than a hot summer which the laurei demands, and the same may be said of the fig-tree. The olive, on the other hand, requires prolonged summer heat to enable it to perform its vital functions. Saporta describes the fig-tree of the La-Celle tufa as closely approximating, in the size and shape of its leaves and fruit, to that of the tufas in the south of France, and to those of Asia Minor, Kurdistan, and Armenia. But if the winters in Northern France were formerly mild and genial, the summers were certainly more humid, and probably not so hot. This is proved by the presence of several plants in the tufa of La Celle which cannot endure a hot arid climate, but abound in the shady woods of Northern France and Germany."

The plants found in the tufas of Canstadt are much similar to those of Moret. Mr. Howorth, in regard to the deposits of 
those places, says :- "The coexistence of the species found there, remarks M. Saporta, proves very clearly that, notwithstanding the variations due to latitude, Europe, from the Mediterranean to its central districts, offered fewer contrasts, and was more uniform than it is now. A more equable climate, damp and clement, allowed the Acer pseudo-platanus and the fig to live associated together near Paris, as it allowed the reindeer and hyæna. The Acer grows with difficalty now where the Ficus grows wild, while the latter has to be protected in winter in the latitude of Paris."*

Equally conclusive is the testimony borne by the Mollusca of the tufas. In the tufas and marls of Moret, iri the valley of the Seine, thirty-five species were discovered. The majority of these must have lived in damp and shady places, in the recesses of moist woods, and on the leaves of marsh-plants. The shells, M. Tournouër concludes, bespeak a condition of climate more uniform, damp, and equable than now prevails in that region, with a somewhat higher mean annual temperature. In the alluvial deposits of Canstadt, in Würtemberg, a class of shells indicating a similar condition of climate has been discovered.

The evidence furnished by the animals found most abundantly with the Mammoth in Europe and Siberia, Mr. Howorth thinks, points to the same conclusion as that of the plants and mollusea.

The same mild and equable condition which allowed of the Mammoth living in Northern Siberia during Pleistocene times thus equally prevailed over the whole of Europe. We have seen that, according to the Physical Theory, this condition of climate was in every respect precisely what it ought to have been on the supposition that it was interglacial. It was a condition mild, equable, uniform, humid, and of a higher mean annual temperature than we have at the present day. There is, however, direct and positive evidence that this condition of climate was interglacial; for the facts both of geology and of palæontology show that it was preceded and succeeded by a state of things of a wholly opposite character.

The Mammoth Glacial as well as Interglacial.-Although the Mammoth could have lived in Aretic Siberia only during an interglacial period, it does not follow that it must have perished during the succeeding glacial period. When the cold came on, and the regetation on which it subsisted began to disappear, it would move southwards, and would continue its march as the cold and severity of the winters increased.

* Geol. Mag. June 1881 . 
During the continuance of the ten or twelve thousand years of Arctic conditions it would find in Southern Europe and elsewhere places where it could exist. At the end of the cold period, and when the climate again began to grow mild and equable, it would retrace its steps northwards. There is, however, little doubt that during the severity of a glacial period, and when necessarily confined to a more limited area, its numbers would be greatly diminished. There is every reason for believing that the Mammoth outlived all that succession of cold and warm periods known as the glacial epoch proper, and did not finally disappear till recent postglacial times.

It was probably about the commencement of a cold period, and before the Mammoth had retreated from Northern Siberia, that those individuals perished whose carcases have been found frozen in the cliffs. The way in which they probably perished and became imbedded in the frozen mud and ice, has, I think, been ingeniously shown by Dr. Rae*.

Arctic America during Interglacial times.-We have seen that the eastern continent in Pleistocene times enjoyed in the Arctic regions interglacial conditions of climate. It is true that on the western continent we have not in Aretic regions such clear and satisfactory evidence of an interglacial period. But it would be rash to infer from this that the western continent was, in this respect, less favoured than the eastern. That we should find less evidence at the present day of former interglacial periods in Arctic America than in Arctic Asia, is what is to be expected, for the glaciation which succeeded interglacial periods has been far more severe in the former region than in the latter. The remains of the Mammoth have, however, been found in Arctic America, in ice-cliffs at Kötzebue Sound, under conditions exactly similar to those of Siberia.

In Banks's Land, Prince Patrick's Island, and Melville Island, as in Northern Siberia, full-grown trees have been found in abundance at considerable distances in the interior, and at elevations of two or three hundred feet above sea-level. The bark on many of them was in a perfect state. Capt. McQlure, Uapt. Osborn, and Lieut. Mecham, by whom they were found, all agreed in thinking that they grew in the place where they were found.

It is true that more recent Arctic voyagers have come to the conclusion that these trees must have been irifted down the rivers from the south. There can be little doubt that the greater part of the wood found there, as in Siberia, is driftwood. But may there not be, also, as in Siberia, two kinds

* Phil. Mag. for July 1874, p. 60. 
of wood?-a "Noashina" and an "Adamshina," a kind which was drifted and another kind which grew on the spot. This is a point which will require to be determined.

That so little has as yet been done in the way of searching for such evidence of interglacial periods, is, doubtless, in a great measure due to the fact that most of thosé, if not all, who have visited those regions entertained the belief that there is an $\dot{a}$ priori improbability that a condition of climate which would have allowed the growth of trees in such a place prevailed so recently as Post-tertiary times. Even supposing those Arctic voyagers had considered the finding of interglacial deposits a likely thing, and had in addition made special search for them, the simple fact that they should have failed to find any trace of them could not, as we have already shown, be regarded as even presumptive evidence that none existed. Take Scotland as an example. Abundant relics of interglacial age have there been found from time to time; but amongst the many geologists who visit that country year by year, how few of them have the good fortune of discovering a single relic. In fact a geologist might search for months, and yet fail to meet with an interglacial deposit. The reason is obvious. The last ice-sheet, under which Scotland was buried, was so enormous as to remove every remnant of the preceding interglacial land-surface, except here and there in deep and sheltered hollows, or in spots where it may happen to have been protected from the grinding power of the ice by projecting rocks. But all those places are now so completely covered with boulder-clay and other deposits that it is only in the sinking of pits, quarries, in railway-cuttings, and other deep excavations that traces of them accidentally turn up. Now if it is so difficult to find in temperate regions, in a place like Scotland, interglacial remains, how much more difficult must it be to meet with them in Arctic regions, where the destructive power of the ice must have been so much greater.

Something like indications of an interglacial period appear to have been found by Professor Nordenskjöld in Spitzbergen. "In the interior of İce-fjord," he says, "and at several other places on the coast of Spitzbergen, one meets with indications either that the polar tracts were less completely covered with ice during the glacial era than is usually supposed, or that, in conformity with what has been observed in Switzerland, interglacial periods have also occurred in the polar regions. In some sandbeds not very much raised above the level of the sea one may, in fact, find the large shells of a mussel (Mytilus edulis) still living in the waters encircling the Scandinavian coast. It is now no longer found in the sea around 
Spitzbergen, having been probably routed out by the ice. masses constantly driven by the ocean-currents along the coasts." *

This testimony is the more valuable as it is given by an experienced geologist so much opposed to the theory of interglacial periods. A more special and thorough search of those beds might probably reveal further indications of interglacial age.

Was Greenland free from Ice during any of the Interglacial Periods?-There is nothing whatever improbable in the supposition that during some of the earlier interglacial periods, when the eccentricity was about a maximum, the ice might have completely disappeared from Greenland, and the country become covered with vegetation.

Mr. Wallace thinks that the existence at present of an ice-sheet on Greenland is to be explained only by the fact that cold currents from the polar area flow down both sides of that continent. $\mathrm{He}$ further thinks that could these two Arctic currents be diverted from Greenland, "that country would become free from ice, and might even be completely forest-clad and habitable." $\dagger$

I am inclined to agree with Mr. Wallace in thinking that the withdrawal of the two cold currents in question would effectually remove the ice. We know that Greenland is at present buried under ice, as has been shown on former occasions, simply because there happens to be about two inches more of ice annually formed than is actually melted. It certainly would not require any very great change in the present physical and climatic conditions of things to melt two additional inches per annum. If this were done the ice would ultimately disappear. A simple decrease in the volume of the two currents might possibly bring about such a result. A cause more effectual would, however, be an increase in the temperature and volume of the Arctic branch of the Gulf-stream.

NoTE.-This will probably be my last paper on questions relating to geological climate. There are many points I should have wished to consider more fully, but advancing years and declining health have rendered it necessary for me to abandon the subject altogether in order to be able to finish some work, in a wholly different field of inquiry, which has been laid aside for upwards of a quarter of a century.

* "On former Climate of Polar regions," Geol. Mag. Nov. 1875, p. 531. See also "Geology of Spitzbergen," Geol. Mag. 1876, p. 267.

$\dagger$ 'Island Life,' p. 149. 